\title{
한국의 다자원조 현황과 과제
}

박 재 영 / 경상대학교 정치외교학과 교수

\section{I. 서론}

국가 간에 물리적인 국졍이 낮아지고 상호.의존이 심화 되면서 일국의 문제가 국제사회의 문제로 쉽게 전이되 곤 한다. 시구화시대의 주요한 문제와 도전이 이처럼 한 나라의 국경 내에 머물지 않고 확산됨으로써 이러 한 문제와 도전의 해졀책이 일국이 아닌 국제사회 전 체에 의해 마련되지 않을 수 없게 되어가고 있다. 따라 서 국제사회의 문제해결 방식으로서 다수 국가간의 헙 럭을 의비하는 다자주의(multilateralism)의 중요성이 증대하고 있다.

이러한 다자주의의 중요성은 빈건과 저발전을 극복하 기 위한 개발원조 분야에 있어서도 예외가 아니다. 유 엔은 2000년에 '천년개빌목표(MDGs)'를 설정한 후 지속적으로 중간점점과 더불어 후속조치를 취해오고 있고, 2002 년에는 빈곤퇴치와 개발재원의 확보를 위 한 '몬테레이 합의(Monterey Consensus)' 를 채택한
바 있다. 경제협력개발기구 개발원조위원회(OECD /DAC)의 경우 2005 년에 '원조 호과에 관한 파리선언 (Paris Doclaration on Aid Effectiveness)'을 채택하 였으며, 2008년에는 이러한 파리선언의 이행에 대한 중간점검과 더불어 파리선언의 내용을 구체화한 아 크라 행동계획 (Accra Agenda for Action: AAA)을 채택한 바 있다.

이처럼 국제기구가 중심이 되어 저발전과 빈곤의 문제 를 해결하기 위해 다사적인 노력을 활발하게 전개하고 있는데, 이러한 노럭의 본질적인 이유는 이러한 문제 가 다국적이고 다면적인 접근이 없이는 해결의 실마리 를 찾기 어렵다는 절박한 인식에 기초한다. 이러한 노 력의 저변에는 뜨한 개도국의 저발전과 빈린의 문제가 국제사회에 갈등과 분쟁을 촉발하고 나아가 9.11테러 등을 유발하는 등 선진국에게도 심각한 위협이 되고 있다는 인식이 자리하고 있다. 게발원조의 역사가 입 증하듯이, 개도국의 빈iㄴㄴㄱㅘ 저발전의 문제가 자신들에 
게 실질적인 큰 위협으로 다가온다고 인식하는 겅우 선진국들은 보다 적극적으로 국제적인 해결책을 모색 해오곤 했다.

개발원즈를 둘러싼 이러한 인련의 국제협력이 국제기 구를 통한 원조를 의미하는 다자원조의 중요성에 집중 할 것이라는 예측과는 달리, 양사원조와 다사원조를 구분하지 않고 총체적으로 효율성을 제고하기 위한 집 딘적인 노력의 중요 성을 강조하고 있다. 이는 총 원조 중 양자원조가 차지하는 비중이 $70 \%$ 정도를 차지하고 있다는 현실이 반영된 것으로 볼 수 있다.

국내직으로나 국제직으로 개빌원조의 국제헙력이 강조되는 가운데 다자원조에 대한 관심은 양자원조 에 미치지 못하고 있는 것이 현 실이다. 한국의 개발 원조와 관련하여 논의를 전개할 경우 무상원조의 비율을 곺여야 하며 구속성 원조(tied aid)의 비율 을 낮추어야 한다. 뜨한 개발원즈를 체계적으로 운 영하고 집행할 수 있도록 대외원조기본법을 제정하 여야 한다. 최근에는 경제협력개발기구의 개발원조 위원회 $(\mathrm{OECD} / \mathrm{DAC})$ 에 가입하여야 한다는 점 등이 횔반하게 논의되어 오고 있다. 그러나 개발원즈와 관련하여 좀 더 이상적인 제언을 해오는 비정부기 구(NGO)에게서 조차도 다자원조에 대한 관심은 서 조하다. 따라서 본 논문은 현재 한국의 개발협럭이 전환점에 있다는 인식하에, 다자원조에 있어서 한 국이 취하여야 할 태도가 무엇인가를 이끌어내는 것을 목표로 논의를 전개하고자 한다.

\section{II. 다자원조의 개념과 다자원조 국제기구들}

원조는 보통 양자원조(bilateral aid)와 다자원조 (multilateral aid)로 구분된다. 흔히 공여국으로부터 수원국에 직접 제공되는 원조를 양자원조라고 하고, 국제기구를 통한 원조를 다자원조라고 한다. 그러나 이러한 이분법적인 구분은 현실과 일정한 귀리를 가지 고 있는 것이 사실이다. 따라서 여기에서는 본격직인 다자원조에 대한 논의에 앞서 보다 세밀하게 다자원조 란 개념이 무엇을 의미하는가를 우선적으로 검토하고, 이러한 다사원조와 관련 있는 국제기구에는 어떠한 것 들이 있는지 살퍼보고자한다.

\section{1. 다자원조의 개념}

경제협릭개발기구(OECD)는 다자기여(multilateral contribution)를 다음과 같은 특징을 보유한 조직에 제 공되는 기여라고 정의하고 있다. 1) 활등의 전부 혹은 일부가 개발(development)을 위한 조직이어야 한다. 2) 정부를 회원으로 하는 국제적인 조직이거나 이러한 조직에 의해 자율적으로 관리도는 기금(fund)이어야 한다. 3) 기여금(ontribution)을 한 군데로 모음으로 써, 누구로부터 온 기어금인가의 정체성(identity)을 상 실한 채 재정적인 자원의 총체적인 부분이 되도곡 하 는 조직이어야 한다.

어기에서 다자원조의 개념을 구성하는 세 번째 요소에 주목할 필요가 있다. 이에 대한 $\mathrm{OECD}$ 의 입장을 비연하 면, 만약에 공여자가 수원국을 틎정하든가 혹은 목적, 
조건, 총액, 상횐 금의 재사용(reuse of repayments) 과 같은 지출의 다른 측면을 특정하여 기금의 사용을 효과적으로 통제하는 경웅 이더한 기여금은 양자적인 것으로 분류된다". 즌 다자기여란 국제조직에 대해 조 긴을 부과하지 않고 중앙 집중적으로(centrally) 제공 되는 기여금만을 의미한다.

현실적으로 많은 공여구들이 기금제공 채닐로서 국제 기구에게 기여금을 제공하면시 수원국과 용도를 지정 하는 조건을 부과하곤 한달. 이러한 원조는 국제기구 에게 제공된다는 점에서 다사원조이나, 공여국이 수원 국이나 용도를 지정하여 제공한다는 전에서 양자원조 로서의 성격을 지닌다. 따라서 이러한 원조를 다양자 원조(multi-bilateral assistance) 라는 제 3 의 원조형 태로 분류하기도 한다.

이처럼 조건이 수반되어 국제기구에 제공되는 원조 를 $\mathrm{OECD}$ 의 경우처럼 양자원조루 분류할 수도 있 고, 다자원조도 양자원조도 아닌 다양다원조라는 제 3 의 형태로의 분류도 가능하다. 이 논문에서는 이러한 원조가 OECD 통계에는 양자원조로 간주된 다는 점을 염두에 둔 가운데, 논의의 편의상 잠정적 으로 양자적인 성격을 갖는 다자원조로 간주하고자 한다.

\section{2. 다자원조 국제기구}

다자원조를 제공하는 다자기구는 여러 기준에 의해
구분되는데, 가장 일반적으로 이루어지는 구분이 국제금응기구인가의 여부에 따른 구분이다. 이에 따르년 다자원조 국제기구는 국제 금응기구 (International Financial Institutions: IFIs)와 비 금융기구(Non-Financial Organizations: NFOs)로분리된다.

국제금응기구에는 세/계은행(IBRD), 국제동화기금 (IMF), 아시아개반은행 $(\mathrm{ADB})$ 과 같은 지역개발은행 (regional development hank) 등이 포함된다. 비금응 기구로는 유엔(UN), 유엔개발계획(UNDP) · 유엔아동 기금(UNICEF) - 유엔난민고등판무관실(UNHCR)과 깉은 유엔의 산하기구, 세계보건기구(WHO)를 위시한 17 게의 전문기구(specialized agencies), 유럽연합 $(\mathrm{EU})$ - 아프리카연합(AU)과 같은 지역기구(regional organizations) 등이 있다.

이러한 구분 이외에 개반원조에 중점을 두고 있는 국 제기 구인가 아니면 긴급 구호에 중점을 두고 있는 가구 인가에 따른 구분도 가능하다, 유엔개발계획(UNDP), 세계은행(IBRD), 지역 개빌 은행 등이 개빌원조에 중짐 을 두고 있는 국제기구로 분류되고, 세계식량계획 (WFP), 유엔아동기금(UNICFF), 유엔난민고등판무관 실(UNHCR) 등이 긴급구호 등 인도주의적 시원에 중 전을 두고 있는 국제기구로 분류된다. 본 논문에서는 개반원조 관련 다자기구를 국제금응기구와 비금응기 구로 구분하여 살펴보고자한다.

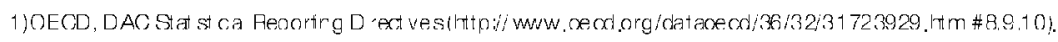

2)좀좀 이러한 기여금은 나아가 프로젝트의 지도자로서 공여국 출신의 스태프를 고옹히라는 것과 갇은 숨겨진 조긴은 포함하기도 한다. 


\section{III. 다자원조의 형태}

국제금융기구의 경-우, 다사원조는 출사금(capital subscriptions)과 출연금(contributions)이라는 형태로 이루이진다 ${ }^{3)}$. 비금응기구의 경우, 출연금 (oontributions)이라는 형태로 다자원조가 제공되는 데, 구체적으로 정뀨예산 분담금이라고 불리는 강제성 이 있는 출연금과 강제성이 없는 자발적 출연금 (voluntary contribution)으로 구성된다. 이러한 출자 금과 출연금에 더하여 국제기구에 대한 양허성 차관 (concessional lending)의 제공이 다자원조의 한 형태 를 구성한다.

국제개발협회(IDA)와 아프리카개반은행(AfDB)을 중 심으로 과다채무 빈곤국의 채무탕감을 위해 추진 중인 '다자채뭍탕감이니셔티브(Multilateral Debt Relief Initiative: MDRI)' 에의 재원제공과 같은 것도 다자원 조의 하나로 간주된다. 다음에서 국제기구를 국제금응 기구와 비금응기구로 구분하여 다자원조의 형태를 좀 더 세밀하게 살펴보고자 한다.

\section{1. 국제금융기구를 통한 다자원조}

국제금융기구의 경우 일반적으로 출자금, 출연금, 차 입금에 의해 운영된다. 출자금(subscription)만으로는 융자수요를 충좃시킬 수 없을 경우, 가입국의 출연금 (contribution)에 의한 재원보충(replenishment)을 통
해 추가재원을 조달하고 있다. 여기에서 출자금은 투 표권을 부여받는 반면, 출연금은 일종의 기여금으로서 원칙적으로 투표귄이 비여되시 않으며, 출자금은 탈퇴 할 때 환급대상이 되나 출연금은 환급대상이 되지 않 는닿․

출사금의 경우 다사원조에 포함되시 않는 반면, 출연 금의 경우 다자원조로 간주된다. 그러나 실제에 있어 서 출연금의 성격을 가지면서 외양상 출자금으로 분류 되는 경우가 있는데, 이런 경우 다자원조로 간주된다. 예컨대, 국제개발헙회(IDA)의 경우 한국정비가 재원보 충(replenishment)을 위해 기금을 제공하는데, 이는 출자금의 외양을 지니나 실제에 있어 출연금이기 때문 에 다자원조에 포함된다.

아시아개발은행(ADB)의 예를 들면, $\mathrm{ADB}$ 의 융자재원 은 출자금과 특별기금으로 분류된다. 특별기금은 저개 발 회원국에 대한 응자와기술지원을 위한 기금으로 사 용-되며, 가입국의 출연금으로 충당된다. 한국정부는 2006년에 'e-Asia 및 시식협력사업 기금' 을 설치하는 협정을 $\mathrm{ADB}$ 와 체결하고, 이 기금에 대한 출연을 시작 한 바 있다. 이는 신탁기금으르서 주로 아시아 개도국 의 정보화와 국가 간 정보격차 해소를 위해 사용된다케.

이처럼 개개 공여국은 국제금융기구와 신탁기금 협정 을 체견하여 출연금을 제공하기도하고, 국제금융기구 가 독립적으로 관리하는 기금에도 출연금을 제공하곤

3) OECD 톻계에서는 출연금을 'Contribut or' 이라고 표기히지 않고 ' $\mathrm{g}$ ‘ant' 로 표기한다.

4)한국 외표통삼부는 ‘점규예산 분담금' 을 ‘의무분담금' 이라고도 부른다. 또한 '자발적 출연금'의 경우 ‘사업 분담금' 이라는 옹어를 시옹한다. 5) IDA 융자재원의 대부분을 이루는 회원국의 출은금 중 일부는 출자금으로 인정되기도 한다. 
한다. 국제 에이즈 · 걸핵 · 말라리아 퇴치기금(Global

Fund to Fight AIDS, Tuberculosis and Malaria:

GFATM)과 국제환경기금(Global Environment

Facility: GEF)을 위시한 많은 다자기금(multilateral fund)이 국제금응기구에 의해 설치되어 관리되고 있 다. 국제금융기구가 관리하는 기금에 출연을 많이 하 는 공여국의 경욱 기구 내의 의사결정에서 상당히 많 은 권력(power)이 주어져 이들에 내한 정당성 (legitimacy)이 논의의 대상으로 지속적으로 되이오고 있다.

\section{2. 비금융기구를 통한 다자원조}

비금융기구의 경우, 앞서 인급했듯이 공여국들은 정규 예산 분담금과 자발적인 출연금의 형태로서 원조를 제 공할 수 있다. 이들을 나누어 살펴보면 다음과 같다.

\section{가. 정규예산 분담금}

정규예 산 분담금은 통상적으로 국가의 시불능력 (capacity to pay)을 근거로 산출되어 강제적으로 부과 된다. 따라시 일빈적 으로 공여국과 수원국을 불문하고 국제기구의 회원인 이상 최소한의 분담금을 부담하여야 한다. 이너한 분담금은 국제금융기구의 출사금과는 달 리 배년 지불하는 기여금으로서 다자원조로 간주된다.
그러나 게게 공여국이 개게 국제기구에 제공하는 분담 금 전체가 모두 다자원조로 간주되는 것이 아니다. 특 정 국제기구의 활동이 얼마나 개발과 관련 된 활동이냐 에 따라서 개개 국가가 분담한 장규예산 분담액 전체 가 다자원조로 간주되기도 하고, 일부민이 다자원즈로 인정되기도 한다. 예컨대, 세계식량계획(WFP)과 유엔 공업개발기구(UNIDO)의 경우 분담금의 $100 \%$ 가 공적 인 개발원조로 인정되나 세계보건기구(WHO)는 $70 \%$, 식량농업 기구 $(\mathrm{FAO})$ 의 경우는 $51 \%$ 가 인정비율이다. 유 엔 정규예산 분담금과 평화유지활동( $\mathrm{PKO}$ 부담금은 각각 $12 \%$ 와 $7 \%$ 딴이 다사간 $\mathrm{ODA}$ 로 간주된다. 세계시 적재산권기구(WIPO)의 분담금은 $3 \%$ 만이 인정된다.

한국의 경우 국제사회에서 11 위 정도의 경제력을 보유 하고 있어 이에 상응하는 높은 비율의 분담금을 유엔 을 위시한 각종 국제기구에 제공하고 있는데, 많은 국 제기구에서 부분적으로만 개발원조로 인짐을 받고 있 다고 볼 수 있다.

\section{나. 자발적 출연금}

\section{1) 자발적 출연금에 대한 의존의 심화}

비금융기구의 경웅 정규에산 분담금만으로 필요한사 금을 확보할 수 없는 경우나 종래 동상적인 예산에 규

6)이러한 기금의 운염에 있어서 한국의 영향력이 크게 작용한다. 우선 지원 대삼사업을 선점함에 있어 한국과 협의를 하도록 하고 정보기술(IT) 분야 듬 우리 기업이 세계적 경젱력을 가진 부문에 우선권을 부여함으로 씨 앞으로 한국기업의 $\mathrm{ADB}$ 사업에 대한 수주가 점차 확대되고 아시아 시장 진츨에 크기 기여할 것으로 본다. 한국정부는 또한 국내 전문가 리스트를 $\mathrm{ADB}$ 에 제공히여 $\mathrm{ADB}$ 시업 주체 선정과정에 국내의 우수한 인력이 우선적으로 참여할 수 있도록 함 으로써 한국의 우수한 인려이 세계 시장에 진출하는 기회를 획대하는 것도 목표의 하나로 하고 있다. 한국정부는 이 기금의 설치를 계기로 과거 소극저이 던 우리의 곡제원조를 확대하여 향후 곡제사회에서 재원공여곡 으루서 위상을 강화할 계획이며, ADB 뿐만 아니라 세계은행(IBRD)가 유럽부흥개 발은행 (EBRD) 등 다든 국제금융기 구에도 유사한 기금의 설립을 추진 줌이다.

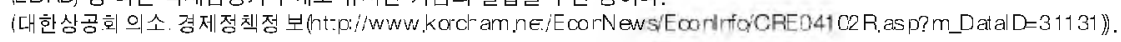

7) 2001 년에 설립된 국제에이즈 · 결핵 - 말라리아퇴 치기금(GFATM)은 2006년도에 공적인 다자원조 촘애의 $6 \%$ 를 지원받은 바 있다. 
정되어 있지 않은 새로운 프로그램을 실시하고자 할 때, 별도의 자발적 출연금을 필요로 한다. 국제기구에 따나 다르나, 이더한 사발적 출연금은 통상 회원국 정 부, 다른 국제기구, 개인 기부자 등에 의해 제공되어 통상적인 예산과는 변도의 기금으로서 운영된다.

유엔의 경인 냉전 종식 후 많은 전 시구적 이슈를 다 루면서 예산의 증액 필요성이 크게 내두되고 있으나, 미국의 압력으로 인하여 정규예산의 대폭적인 증가 가 억제되고 있다. 이 때문에 유엔의 다양한 활동을 재정적으로 시원하기 위해 자발적 출연금을 추구하 지 않을 수 없게 되었을 뿐 아니라, 과거 통상적으로 징규예산에 의해 지원되던 활동들이 짐차직으로 자 발적 출연금에 의해 지원되지 않을 수 없게 되어 가 고 있다.

여러 국제기구 중 틍히 개빌과 구호에 관여하고 있는 비금융기구든은 자반적인 출연금에 대한 의존두가 매 우 높다. 유엔의 경우 자발적 출연금은 통상 유엔의 '계획(program)' 과 '기금(fund)'나고 불니는 산하기 구의 중요한 재정원천이 되고 있는데, 이러한 기구에 는 유엔개발계획(UNDP), 유엔여 성개발기금 (UNIFFM), 세계식량계획(WFP), 유엔 인구기금 (UNFPA), 유엔아동기금(UNICEF) 등이 있다. 이들은 자체 내에 정규예산 분담금이 전혀 없을 뿐 아니라 유 엔본부의 정규예산으루부터의 지원도 전혀 없는 가운 데 전적으로 자발적 출연금에 의존하고 있다. 전문기 구들의 경우는 자체의 정규에산 분담금과 더불어 자발 적 출연금을 동해 개발원조를 제공하고 있다.

\section{2) 자발적 출연금의 장점과 단점}

정규예산 분담금의 경우 강제적인 것으로서 회원국은 자신의 분담금이 원하지 읺는 프로그램 등에 사용되는 것을 통제하는 것이 이렵다. 이와는 달리 자발적 출연 금의 경우 자신이 원하는 프로그램에만 재정적인 지원 을 할 수 있어 자발적인 참여를 확보하기가 용이하다 는 장전이 있다.

이러한 장점과는 달리, 자발적 출연금은 회원국의 자 발적인 의사에 의존하기 때문에 어느 정도의 기금이 확보될 수 있는가에 대한 예측이 어려워 구체적인 프 로그램을 짜서 확징짓는 것이 어렵다. 이 때문에 자발 적 출연금에 크게 의존하고 있는 국제기구들은 2000 년부터 3년을 단위로 하는 '다년 도자금조달틀(MultiYear Funding Framework: MYFF) 을 실시해 오면 서, 자발적 출연금 제공국들에게 다년간에 걸친 출연 금 제공의 약속을 촉구하고 있다.

또한 유엔개발계획(UNDP)의 경웅 상위 10 개 공여국 이 제공하는 자발적 출연금이 전체 자빌적 출연금의 $85 \%$ 내외를 차지해 오고 있다는 사신에서 보듯이, 자 발적 출연금에 의해 운영되는 국제기구가소수의 국가 에게 재정적으로 크게 의존하고 있다. 따나서 이들에 의해서 프로그램이 영향을 받지 않을 수 없다. 즉, 이 들 주요 공여국들은 자반적 출연금의 제공을 줄인 수 있을 뿐 아니라 중단할 수도 있기 때문에, 국제기구 사 무국은 자발적 출연금을 제공하는 국가(들)의 견해를 무시하는 모험을 감행하기 어렵다. 따라서 국제기구가 자빌적 출연금에 크게 의존할 경우, 국제기구의 자율 
성이 훼손될 수 있다. 또한 반대하는 회원국이 배제된 가운데 프로그램이 운영되기 때문에, 국제기구 전체의 활동이 아닌 일부 회원 국만의 소위 기구 내 기구의 활 동이 되기 싶다는 문제짐을 가진다.

유엔 헌장 제101조 3항은 국제기구 직원을 채용함에 있 어서 객관적 기준으로서의 능률, 능력 밎 성실과 더불 어 정치적 기준으로서 지리적 배분을 조화시키도목 규 정하고 있으나, 이 규정은 자반적 출연금에 의해 운영 되는 국제기구에는 공식적으로 적용하지 않기로 사전 에 동의된 바 있다. 이더한 동의의 의도는 이더한 기준 에 구애를 받지 않고 자유로이 가장 적절한 사란을 찻 아 직책을 부여한다는 것이었으나, 신진 공여국들이 자신들이 제공하는 자발적 출연금에 대한 통제력을 갖 기 위해 자국의 국적을 가진 사람이 이러한 기금을 제 공반는 국제기구에서 중요한 직책을 갓도록 노럭함으 로써 이러한 동의의 진짐한 의도를 왜곡시키고 있닿․

\section{3) 자발적 출연금의 종류}

자빌적인 출연금은 통상 '핵심기금(core-fund)' 과 '비핵심기금(non-core fund) 이라고 분리는 두 가지 형태를 떤다. "핵심기금(oore-fund)' 이란 용도가 구체 적으로 시정되시 않은 자발적 출연금으로서, 국제기구 의 기본적인 운영, 행정, 프로그램 등을 지원하는 목적 으로 사용된다. 또 다른 종류의 자발적 출연금인 '비핵 심기금(non-core fund) 이란 수원대상과 용도 등과 관련하어 공어국이 부과하는 제약에 구속되는 조건부
출연금이다: 공여국은 최소한의 핵심기금을 제공한 후에야 비핵심기금을 제공할 수 있는데, 이러한 비핵 심기금은 비용분담기금(cost-sharing fund), 신탁기 금(trust fund), 국제기구가 관리를 맡고 있는 기금 (international organizations-administered fund)으 로 구분된다.

비용분담기금은 말 그대로 비용을 공동으로 분담하는 기금으로시, 공여국이 누구와 비용을 분담하는가에 따 라 수원국정부와 비용을 분담하는 경우(government cost-sharing)와 제3자와 비용을 분담하는 경-임 (third-party cost-sharing)로 구분된다. 공여국이 국 제기구와 비용을 분담하는 경우가 후자의 예에 속하 며, 이때 공여국과 국제기구 사이에 비용분담 헙정이 체결된다.

신탁기금은 공여국이 수원국과 용도를 지징하여 국제 기구에 기금을 맡기면, 국제기구는 기금 제공국을 대 신하여 프로그램이나 프로젝트를 대신하여 집행해 주 는 제도를 말한다. 신탁기금은 수원국과 용도를 시정 한다는 의미에서 양자원조의 성격을 지니며, 동시에 국제기구에 기금을 제공하여 국제기구에 의해 관리된 다는 면에서 다자원조의 성격을 지니고 있다. 이를 위 해 개개 공여국은 국제기구와 신탁기금 협정을 체결하 는네, 신탁기금은 득정의 목적, 득정의 프로젝트, 하나 혹은 그 이상의 국가나 지역적 그리고 전 자구적인 프 로그램에 대한 관심 속에 설립된다. 신탁가금은 하나 의 공어국에 제한될 수도 있고 다수의 공어국에게 개 
방될 수도 있다. 국제기구는 일반적으로 이리한 신탁 기금을 관리하는 데 있어서 소요되는 비용을 공여국에 게 부과한다.

국제기구는 개변 공여국의 의뢰에 의한 신탁기금 이외 에 독립적으로 설치한 기금을 관리하기도 한다. $\mathrm{UNDP}$ 가 관리하는 기금의 예를 들사면, 유엔사본개발 기금(UNCDF), 유엔과학기술개발기금(UNFSTD), 유 엔여성개발기금(UNIFEM), 사막화·가뭄방지기금 (UVSO) 등이 있다 ${ }^{110}$.

비금융기구의 자발적 출연금 중에서 비핵심기금이라 고 하면 일반적으로 위에서 인급한 것 가운데 주로 제 3자 비용분담제와 신탁기금을 가리킨다. 이 둘은 모두 공여국이 선택한 주제 분야에서 그들 자신의 프로젝트 를 촉진할 수 있도곡 하녀, 공여구은 국제기구를 유용 한 매개자(intermediary)로 바라보게 된다. 이러한 기 금제공 통로는 국제기구의 전문성, 정치적으로 민감한 프로젝트나 프로그램에 있어서의 중립성, 원조의 조정 (coordination)을 실현하면서 공여국으로 하여금 느들 이 선정한 프로젝트나 프로그램에 영향을 미치는 것을 허용한다. 그러나 양자원조의 경우와 비교해 볼 때, 수 원국과의 보다 직접적인 관계를 구축하는 것이 어렵게 된다. 에컨대, 공여국으로부텅의 서비스와 장비의 조 달 기회와 같은 것이 축소된다.

제3자 비용분담제와 신탁기금 등에서 공여국은 신탁
기금에 의해 공여국의 정책과 관심이 좀 더 직접적으 로 고려될 수 있기 때문에 비용분담제보다 신탁기금을 선호하는 경향이 있다. 즉, 신탁기금은 공여국의 정체 성(identity)과 공여국의 개발목표와의 관계를 보전해 주기 때문에 공여국이 선호한다. 국제기구의 경우는 이와는 달리 그들에게 좀 더 많은 퉁제가 주어지는 제 3자비용분담제를 더 선호한다.

\section{$\mathrm{IV}$. 다자원조의 장점과 단점}

여기에 서는 다자원조가 양자원조와 견주어 상대적으 로 가지게 되는 장짐에 대해 살퍼보고자 한다. 한국수 출입은행(Korea Fximbank)의 원조용어집은 다자원 조의 이점을 개도국의 민족주의 고양에 대응하면서 자본의 국적을 은폐할 수 있는 효과가 있고, 양자원조 와 비교하여 국제기구에 있는 고도의 전문지식과 경 험을 이용할 수 있으며, 정부 주두로 원조가 불가능하 거나 곤란한 국가와 지원에 대하여 원조가 가능하다 는 등의 이점이 있다고 언급하고 있달. 일반적으로 다자원조는 다음과 깉은 장짐과 단짐을 가지고 있다 고 볼 수 있다.

첫째, 공여국이 다사원조 제공시 시정학적인 목표나 경제적 이이을 완전히 배제하는 것은 아니지만, 다자 원조는 인빈적 으로 공여국의 이러한 이익에 던 종속 된다. 즉 다자원조는 공여국의 개별적인 목표를 희석

\footnotetext{
10) 'UNSO'는 과거에 'Unitec NatonsSucaroSane an Offce' 의 악어이었으나명칭이 'Office ㅇ Combat Deseytif caticnard Dought' 루 바뀐 후에도 그 대로 'UNSO' 라는 말을 쓰고 있다.
}

11) 한국수출입 은햄, 원조용어집(http: i www koreaexim go ko) 
시켜 원조의 정치화(politicization of aid)를 줄일 수 있다. 이로 인해 수원국은 비구속성 원조의 혜택을 누릴 수 있으며, 결과적으로 수원국 정부의 정책과 일치시키는 데 기여할 수 있고 수원국의 주인의식 (ownership)을 촉진할 수 있다. 따한 다자원조는 양자 원조에서 공여국의 이해관계로 인해 원조의 대상에서 소외되고 있는 개도국들에게도 원조가 제공될 수 있 다. 전 세:계적인 광번위한 원조의 망을 가지고 있지 않 은 작은 공여국에게 이용의 가치가있게 된다.

둘째, 과거의 식민시 관계 속에서 현재 이루어시고 있 는 양자원조의 경우 이러한 여사적인 연계로 인해 득 징 수원국에 대해 좀 더 많은 지식과 경험을 가지고 있 다고 주장하기도 하지만, 국제기구는 일반적으로 게별 적인 공여국보다 특정 분야에 있어서 광범 위한 지식과 오랜 기간 축적된 경험을 보유하고 있다. 구체적으로 국제기구는 프로그램과 프로젝트의 설계와 집행에 있 어서 누적된 부문변 경험을 가지고 있으며, 종종 개별 적인 공여국에게 잘 알려지지 않은 국가나 지역의 현 시조건(local condition)에 대한 월등한 시식을 가시고 있어 효율적인 원조가 가능하다.

셋째, 다자원조는 이러한 축적된 지식과 경험 이외에 큰 규모의 재정적인 사원을 동원할 수 있다. 국제기구 만이 개개 공여국이 개별적 수준에서는 제공할 수 없 는 규모가 큰 재정적 자원을 동원하여 프로그램과 프 로젝트를 설계하고 집행함으로써 원조의 제공에 소요 되는 거래비용-(transaction cost)을 줄일 수 있다. 이
로써 다자원조는 앙자원조에 비해 좀 더 효율적으로 개발원조와 인도적 지원을 제공할 수 있다. 상당한 재 정적인 자원을 동원할 수 있는 능력은 국제기구에게 상당한 정도의 징치적인 지렛 대를 제공하기도 한다.

넷째, 다자원조는 공여국 사이의 조정(coordination) 을 촉진하고 조화(harmonization)에 기여하여 원조의 효가성을 제고시킬 수 있다. 자신의 우선순위를 가지 고 있는 원조제공의 주체가 늘이나면서, 원조의 분전 화(fragmentation)와 조정의 결여로 인해 원조기관 사 이의 기능과 할동의 중녹이 초래되고 있으며, 이로 인 해 수원국의 행정비용이 증내하고 종국적으로 원조 호 과성의 주요한 장애가 되고 있다. 이와는 딜리 국제기 구를 통해 원조를 제공할 경우, 공여국들 사이의 불필 요하고 비용-이 많이 수반되는 경쟁을 줄이고 분절화와 중첩을 망을 수 있다. 그 결과 수원구의 행정적인 부담 을 딜어 수원국의 거래비용을 줄여줄 수 있다.

다섯째, 다자원조는어느 한 국가의 노력 만으로는 해결 이 어뎌워 다면적이고 종합적인 접근을 필요로 하는 문 제의 해결에 효과적이다. 빈곤과 저빌전의 문제이밀로 이러한 문제의 전형적인 경우이다. 유엔은 최근 든어 기발, 인권, 안보의 문제를 상호 긴밀하게 연관된 문제 로 보고, 이들에 대한 종합적인 접근을 시도하고 있다. 안보의 개년이 인간안보(human security)로 획장되고 개반의 개념이 인간개반(human development)로 획 장되면서, 그 어느 때보다 이러한 문제를 종합적으로 다룰 수 있는 다자원조가 긴요해지고 있다. 온실가스 
의 감소와 같은 전지구적인 공공재(global public goods)를 제공하는 데도 다자적인 처방이 효과적이다.

여섯째, 다자원조는 양자원조에 비해 보편성 (universality), 공정 성 (impartiality), 중립 성 (neutrality), 독립성(independence), 전 지구적 범주 (global reach)를 가짐으로써 상당한 정도의 정당성 (legitimacy)과 신뢰(trust)를 보유한다. 따라서 에이즈 (HIV/AIDS)와 같은 문제뿐만 아니라 민주주의, 인권, 헌법기정, 국제적인 갈등의 해결과 같은 복잡하고 정 치적으로 민감한 문제를 해결하는 데 유용한 채널이 될 수 있다. 또한 이러한 정당성과 신뢰는 호과성을 높 이는 역할을 한다. 다자원조는 이익에 추동된 양자원 조를 권리에 기초한 전 자구적인 재분 배적 정의체제로 변형시키는 전 지구적 기버년스의 레짐(regime of global governance)의 형성에 기여할 수 있다.

다자원조는 이러한 장점들을 가지고 있지만, 이러한 장점은 다자원조 국제기구들 사이의 빈약한 협력, 일 관성의 결여, 느릇된 우선순위 배정, 보실한 관리 (management)로 인해 상실되고 있다는 비판도 받고 있는 것이 사신이다. 거대한 관류조직 으루부터 오는 것으로서 응통성이 부족하다는 지적도 받는다.

국제금응기구를 통한 다자원조는 내규모 차관 패키지 (loan package)의 형태를 띤다. 세계은행(IBRD)이나 국제통화기금(IMF)이 이행조건(conditionality)으로 이러한 차관의 제공과 더불어 부과하는 개도국에 있어
서의 긴축프로그램(austerity program)과 구조조정정 책이라는 것이 차관의 회수에 중점이 주어진 결과, 수 원국의 국내문제에 간섭하고 장기간에 걸처 해를 미칠 수 있다는 비판도 받아오고 있다.

\section{V. 다자원조의 국제적인 추세와 한국의 현황}

\section{1. 다자원조의 국제적 추세 ${ }^{131}$}

경제협럭개발기구의 개발원조위원회(OECD/DAC)는 양자원조와 다자원조의 가장 바람직한 혼합을 달성할 것을 촉구하고 있다. $\mathrm{OFCD/DAC}$ 회원국의 총 $\mathrm{ODA}$ 중 다자원조가차지하는 비율을 보면, 2000 년(32.9\%), 2001년(33.0\%), 2002 년(30.0\%), 2003년(28.0\%), 2004 년(31.6\%), 2005년(23.1\%), 2006년(26.3\%)으로 서 지난 7 년 동안 평균적으로 $29.3 \%$ 의 원조가 다자원 조에 의해 제공되었다 ${ }^{14}$. 즉 총 원조액 중에서 대략적 으로 $70 \%$ 정도가 양사원조를 통해 제공되고, $30 \%$ 정 도가 다자원조를 통해 제공됨을 일 수 있다.

우리가 관심을 가지는 것은 이리한 다자원조의 구성인 데, $\mathrm{OECD} / \mathrm{DAC}$ 의 통계는 다자원조를 크게 출연금과 출자금(Grants and Capital Subscriptions) 그리고 양 허성 차관(Concessional Lending)이라는 두 가지로 분리하고 있다. 이 중에서 관심을 가지고 살펴보아야 할 부분은 출연금과 출자금 부분이다. 출연금과 출자

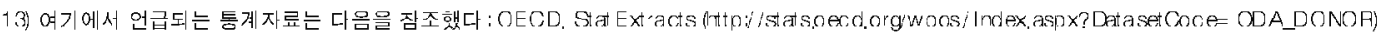
14) OECD 자료이기 따문에 다자원조 중에서 조긴부로 제공된 출연금은 양자원조에 포힘되었다. 
금은 유엔기관(UN Agencies), 유럽공동체( $\mathrm{FC})$, 국제 개발협회(IDA), 세계은행(IBRD) - 국제금응공사 (IFC) - 다국투사보증기구(MIGA), 시역개발은행 (Regional Development Banks), 지구환경기금 (GEF), 몬트리올의정시(Montreal Protocol), 그리고 다른 기관들(Other Agencies)로 세분되는데, 일반적 으로 유엔기관, 유럽공동체(EC), 국제금응기구(IDA, IBRD, IFC, MIGA, 지여 개발은행), 기타로 좀 더 단순 회하여 분류된다 ${ }^{15}$.

여기에서 출사금과 출연금 가운데 국제금융기구, 유엔 기관, 유럽공동체( $\mathrm{EC})$ 에 제공된 기금이 차지하는 비율 을 비교해 보면 다음과 깉다: 2000 년(국제금융기구 $34 \%$, 유엔기관 29\%, FC 28\%), 2001년(국제금응기구 $32 \%$, 유엔기관 31\%, EC 29\%), 2002년(국제금융기구 $32 \%$, 유엔기관 27\%, EC 32\%), 2003년(구제금융기구 27\%, 유엔기관 25\%, EC 36\%), 2004년(국제금융기구 $34 \%$, 유엔기관 20\%, EC 36\%), 2005년(국제금응기구 $30 \%$, 유엔기관 22\%, EC 38\%), 2006년(국제금응기구 $34 \%$, 유엔기관 $19 \%, \mathrm{EC} 35 \%)^{101}$.

2000년부터 2006년까지 국제금융기구의 비율의 평균 은 $32 \%$ 이고, 유엔기관의 비율의 평균은 $25 \%$ 이다. 그 리고 $\mathrm{EC}$ 비율의 평균은 $33 \%$ 이다. 여기에서 흥미로운 것은 $\mathrm{OECD} / \mathrm{DAC}$ 회원 국들이 $\mathrm{EC}$ 를 가장 선호하는 기 금제공 채넌로 횔용하고 있다는 점이다. 2006 년이 다
소 예외이기는 하니 $\mathrm{FC}$ 가 차지하는 비율이 점차적으 로 증가하고 있는 것도 흥미로운 일이다.

$\mathrm{OECD} / \mathrm{DAC}$ 의 가이드라인은 국제기구에 제공하는 출 연금에 즈긴이 붙여시는 안 된다고 권고하고 있다. 핵 심기금(core fund)이야말로 공정하고 보편적인 다자 원조를 제공하는 주된 수단으로서 어떠한 국제기구도 핵십기금 없이 진정으로 다자적일 수가 없다는 인시 때문이다. 그러나 공여국들은 핵심기금에 출연금을 제 공하는 대신, 자국과 이해관계가 있는 특정 지역이나 국가에 목표를 다는 신탁기금이나 비용분담기금을 선 호하고 있다. 그 걸과, 조건부 출연금이 증가하여 개개 전통직인 원조환경을 위헙하고 개발원조의 호율성에 도전을 가하고 있다.

이러한 조건부 자발적 출연금의 증가로 인해 국제기구 가 기금을 받아 스스로의 기시직인 판단에 의해 프로그 램이나 프로젝트를 계획하고 집행해-오던 전통적인 틀 이 깨지고, 프로그램이나 프로젝트의 분절화 (fragmentation)가 촉진되고 있다. 특히 신탁기금 제도 는 공여국이 원하는 국가에게만 기금이 제공되고 이들 이 원하지 않는 국가에게는 이러한 기금이 제공되지 않 도록 함으로써, 국제기구의 다자주의를 변모시키고 있 을 뿐 아니라 관니상의 문제, 책임성(accountability) 의 문제, 예측 가능성의 저하의 문제를 야기하고 있다 는 비판을 받고 있다 ${ }^{17}$.

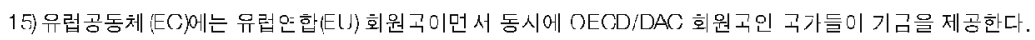

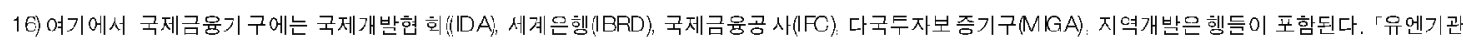
(UN Agencesij이라고 하면 통상적으로 전문기구는 제외되나 $\mathrm{OECD}$ 의 통계상에는 유엔기구와 더불어 전문기구가 포함된다.

17) Department of Puolic Irformaticn of the Urited Nat ors, Memoer Sazes Pedge Aporoxmaty $\$ 80$ Mill on in Suoport cf Unied Nat ons deveopmert Act v tiesfor 2008 (Genera Assemby DEV/2646) (12/November/2007). 
이리한 조건부 자발적 출언금의 증가는 다자기구들이 스스로 초래한 문제이기도 하다. 다자기구들은 제한된 기금을 둘더싸고 서로 치열하게 경쟁하는 가운데, 새 로운 기금을 유치하고 양자원조로부터의 기금을 유인 하기 위한 방편의 하나로서 신탁기금과 같은 기금제공 창구를 경쟁적으로 도입헸고 다자원조의 압력을 받는 공여국들이 자신들이 제공하는 기금에 대해 일정한 통 제러이 주어지는 이러한 조건부 자발적 출연금에 크게 호응한 견과인 것이다.

유엔의 관련 문건들은 자발적 출연금에 의해 운형되는 유엔기구의 자발적 출연금의 총액이 증가하기는 했으 나, 이 중에서 용도를 지징하지 읺고 제공하는 지원이 차지하는 비중이 줄고 있는 반면 용도를 지정하여 제 공하는 자원의 비중이 늘고 있다는 다자원조의 양자 화(bilateralization of multilateral aid)를 이구동성 으로 지직하고 있다.

유엔의 산하기푸 중에서 유엔으로 지원되는 정규에산 의 일부와 자체의 사발적 출연금에 의거하여 운영되는 국제기구 가운데 하나인 유엔마약범죄기구(UNODC) 의 2007 년도 재원구성을 보자. 총 1 억 9,500민 달러 예산 가운데 유엔 정규예산으로부터의 지원이 전체 예 산의 $8.3 \%$ 를 차시했고, 사발적 출연금은 전체 예산에 서 $917 \%$ 를 차지했다. 이러한 자발적 출연금 총액 가 운데 용도를 지정하지 않고 제공된 출연금의 비율은 $8.2 \%$ 에 불과하고, 나머지 $91.8 \%$ 에 해당하는 기여금은
용도가 지정되어 제공되었다 ${ }^{180}$. 이로부터 알 수 있듯이 자발적 출연금에 대한 의존비율이 압도적으로 높고, 이너한 자발적 출연금마서 거의 대부분이 조건부로 제 공되었다.

유엔의 산하기구 중에서 유엔 정규예산으로부터의 지 원도 없이 전적으로 자발적 출연금에 의해 운형되는 국제기구 가운데 하나인 유엔개발예획(UNDP)의 2007년도 재원구성 역시 살펴보자. 총 예산 가운데 즈 건 없이 제공된 핵심기금(oore fund)은 11억 2,000 만 달너인데 반해 조건이 부과된 비핵심기금(non-core fund)은 38억 달러에 달해 전체 예산 가운데 약 $77 \%$ 가 조건부 자빌직 출연금이있다.

이와 관련하여 UNDP 연차보고서(Annual Report)는 이러한 비핵심기금이 핵신기금에 대한 중요한 보완물 이기는 하나 지나치게 비핵심기금에 치우쳐 있다는 것 을 우려하고 있다요. UNDP는 비핵심기금이 공여국들 의 기여에 대해 좀 더 논 통제력을 제공하기 때문에 이 들로 하여금 핵심기금에 기여하도록 하는 것은 매웅 도전적인 일이라고 여긴다. 또 다른 한편 UNDP는 핵 심기금이 감소하고 있는 원인을 $\mathrm{UNDP}$ 의 호율성 (efficiency), 투명 성(transparency), 책임 성 (credibility)에 대한 공여국의 의구심에서 찾고 있다. 이러한 인시하에 이러한 문제들을 해결하기 위한 개혁 을 추진하고 있다.

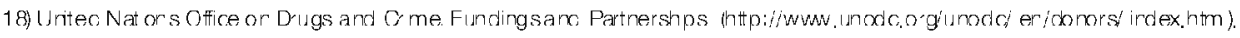
19) UNDP, Annua Report 2008 (ntp: / www. undo,crgublicat or sar nua`epo't2008/resoL'ces, shtm). 


\section{2. 한국의 다자원조의 현황 ${ }^{20)}$}

한국의 총 $\mathrm{ODA}$ 중 다자원조가 차지하는 바율을 보면 다음과 같다: 2000 년(38.1\%), 2001년(35.2\%), 2002년 (25.8\%), 2003년(33.0\%), 2004 년(21.9\%), 2005년 (38.4\%), 2006년(17.4\%). 시난 7년 동안의 비율을 평 균하면 $30.0 \%$ 의 원조가 다자원조로서 제공되었다. 이는 앞서 살펴본 $\mathrm{OECD} / \mathrm{DAC}$ 회원국의 평균과 크게 다르지 않는 수치이다. 그러나 2005년에 $38.4 \%$ 까지 치솟았다가 2006 년에는 $17.4 \%$ 까지 떨어지는 등 기복 이 신한 것이 하나의 득징이라고 할 수 있다로․

2000년부터 2006년까지 7년 동인 다자원조 중에시 국제기구에 대한 양허성 차관(co ncessional lending) 을 제외한 나머지인 출사금과 출연금 중에서 국제금응 기구와 유엔기관에 제공한 기금의 비율을 살피보면 다음과 같다: 2000 년(국제금융기구 $70 \%$, 유엔기관 22\%), 2001년(국제금융기구 62\%, 유엔기관 27\%), 2002년(국제금융기구 63\%, 유엔기관 25\%), 2003년 (구제금응기구 $63 \%$, 유엔기관 18\%), 2004년(국제금융 기구 $71 \%$, 유엔기관 $22 \%$ ), 2005 년(국제금융기구 $83 \%$, 유엔기관 $13 \%$ ), 2006년(국제금응기구 $49 \%$, 유 엔기관 $38 \%$ ).

이 기간 동안 국제금융기구에 제공된 기금의 비율의 펑균은 $66 \%$ 이고, 유엔기관에 제공된 기금의 비율의
펑균은 $24 \%$ 이다. 동일한 기간에 $\mathrm{OECD/DAC}$ 회원국 이 국제금융기구에 제공한 기금의 비율의 평균이 $32 \%$ 이고, 유엔기관에 제공한 기금의 비율의 평균이 $25 \%$ 인 것을 고려할 때 한국의 다자원조에 있어서 국제금 응기구에 대한 편향성이 지극히 강하다는 것을 안 수 있다.

유엔기관에 제공된 출연금(정규예산 분담금과 자발적 출연금)의 내역을 산펴 보면 다음과 같다. 우선 총액 면 에서 상당히 미미하다. 2003년에 2,288만 달러, 2004 년에 2,104만 달러, 2005년에 2,324만 달러, 2006년 에 2,700만 달러 정도에 그치고 있다. 유엔 정규예산 분담률에 있어 한국은 11위에 머물러 있는데, 2004년 부터 2006년까지 3년 동안의 유엔기관 지원액의 합계 로 볼 때 한국은 18 위에 머물고 있다. 이와는 대조적으 로 구제금융기구 지분 순위 면에서 22위에 너물고 있 는 한국이 2004년부터 2006년도 사이에 지원한 기금 의 합계 면에서 볼 때 16 위를 차지하고 있다.

유엔기관에 출연된 기금 증에서 정규예산 분담금이 아 닌 자발적 출연금을 살퍼보면, 2003년에 863만 달러, 2004년 819만 달러, 2005년 783만 달러, 2006년 1,237 만 달러이다. 자발적 출연금 중 조건 부의 비핵심기금은 양자원조로 분류되었기 때문에 이더한 숫자는 차발적 출연금 중에서 핵신기금에 제공된 것을 가러키는데 상 당히 미미한수준에 머물고 있다는 것을 안 수 있다.

20) 외교동삼부 $\mathrm{ODA}$ 국의 인도지원과 기 제공한 지료들 참소했다 .

21) OECD지료이기 때문에 다지뭔소 증에서 소건부로 제공된 출얀금은 양지면소에 포핟되었다.

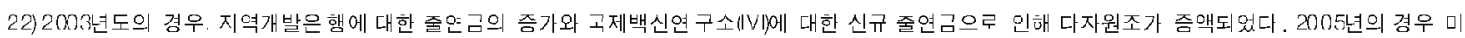
주개발은행 (IDB) 가입에 따른 출지금과 촐연금 그리고 국제개발헙 회|(IDA의 재원보츰으로 인해 에외적으로 다자원조액 이 즘가했다. 2007년의 경우는 $\operatorname{IDA}$ 디 또 다른 재원보춤에 의해 다자원조가 대폭적으로 ㅈㅡㅡ가하였다. 
유엔기관의 자발적 출언금 가운데 조건부 자발적 출연 금의 경우 양자원조로 분류되기 때문에 이를 종합적으 로 추적ㄱ하는 것이 어렵다. 느너나 한국정보 자체가 유 엔개발계획(UNDP)과 깉은 개발원조 제공 국제기구와 공동 프루젝트(joint project)를 통해 다자원조의 모덴 을 구축하고자 하는 방침을 가지고 있는 등으로 미루 어 볼 때, 이더한 조건부 사발적 출연금의 비중이 높을 것이라고 판단된다 ${ }^{23)}$.

가장 대표적인 기발 관련 국제기구이면서 자발적 출연 금으로만 운영되는 UNDP에 있어서의 한국의 원조 상 황을 살펴보먼 이러한 경향을 잘 알 수 있다. 2005년 부터 2007년까지의 자료를 보면, 한국징부는 3년 동 안 핵심기금으로서 100 만 달러씩을 일관되게 제공하 여 공여국들 가운데 27 위(2005년), 24위(2006년), 28 위(2007년)에 너문 바 있다. 비핵십기금의 경우, 한구, 징부는 2005 년에 25 만 딜러, 2006 년에 650 만 딜러, 2007년에 270만 달러를 제공한 바 있다. 이러한 통계 는 한국정부가 자발적 출연금의 제공 자체에 인색한 한편, 이너한 자발적 출연금마서도 조건보 제공에 치 중하고 있음을 보여준다.

한국정부는 2007년 9월 30일부터 기도국 빈곤 · 질병 퇴치 시원을 목적으로 한 「국제빈곤퇴치기여금 제도」 를 시행하여 구,제선 탑송객에게 1,000 원의 기여금을 부과하기 시작헸다. 이러한 기여금은 에이즈, 견핵, 만 라리아의 퇴치를 위해 설립된 국제의약품구매기구
(UNITAID)에 제공된다. 동 기여금의 구체적인 집행은 한국정부와 관련 비정부기 구( $\mathrm{VGO}$ ) 및 수원국과의 약 정체결을 통해 이루어시는데, 이너한 점에서 이 역시 조건부 자발적 출연금의 하나이다랴.

\section{VI. 한국의 다자원조 정책방향}

한국국제협력딘(KOICA)이 잠정적으로 제시하고 다자 원조의 추진전략은 다음과 같다. 첫째, 한국정부가 양 사원조로서 시원하기 어너이ㅁㅓㅕ 국제기구들이 명백하 게 비교우위를 가지고 있는 분야와 구가나 지여에 내 해서는 다자원조를 활용하여 원조의 효율성을 증진한 다. 이에 따라 「아프리카 이니셔티브」 등 아프리카 원 조의 경우 다자원조의 비율을 확대한다. 또한 인권, 환 경, 빈곤, 보건, 여성의 세럭화(empowerment of women) 등과 깉은 전 지구직인 이슈들을 다루는 국제 적인 노력에 횔반하게 동참한다.

둘째, 비금융기구를 통한 다사원조의 방식으로서 한국 징부와 국제기구가 상호 비교우위를 가지고 있는 사업 에 대해 공동 프로젝트를 가지는 등 공동협력 사업을 수행을 통해 다자원조의 모델을 구축하고자 한다. 또 한 세계은행과 유럽개발은행 등에 추가적으로 신탁기 금 설치 등을 추진하고자 한다. 즉 핵심기금이 아닌 제 3 자비용분담제를 포함한 비핵심기금의 제공에 치중하 겠다는 목표를 가지고 있다.

\footnotetext{
23) 힌곡정부는 유엔개발계 획(UNDP)뿐만 아니라 세계은햄 (IBAD)과 아시아개발은햄(ADB) 듬과도 공동 프루젝트를 발굴히여 주진하고, 아프리카연 합(AL) 듬 지역기구와의 소규모 프로젝트시 업을 추진하는 듬 국제기구와의 공돟협력 시업에 치줌하는 것을 목표로 하고 있다.

24) 한국정부는 「혁신적 개발재원을 위한 연대기금의 리딩그굽(Leaong Group on So deity Levies to Fund Development)」에도 참기히고 있다
} 
셋째, 국제기발협회(IDA)와 아프리카기발은행(AfDB) 을 중심으로 과다채무빈곤국의 채무탕감을 위해 추진 중인「다사채뭍탕감이니셔티브(MDRI)」재원보충으로 국제사회의 빈곤감추 노력에 적극 참여하고자 한다. 이러한 것들을 침고로 하면시 한국의 다자원즈가 나아 갈 방향에 대해 언급하고자 한다.

\section{1. 다자원조를 이끌어 갈 방향의 설정}

우선, 다자원조 정책을 강력하고 일관되게 이끌어 갈 원칙이 마련되어야 한다. 성공적인 다사정책 (multilateral policy)이란 국제사회에서의 한국의 역 할에 대한 명백하고 현실직인 개념과 직결되어 있다. 국제사회에서 한국은 어떤 역할을 하고자 하고, 어떤 기여를 하고자 하며, 이러한 것들을 구체적으로 어떻 게 실현하고자 하는가에 대해 철학을 가지고 있어야 한다.

한국의 경우, 아직 개발원조 전반을 이끌어갈 이념을 담을 원조헌장이나 정책시침 등이 만들어셔 있시 않 다. 따라서 개빌원조의 한 형태인 다자원조를 이끌어 갈 방향을 이에 앉서 설정하는 것은 부자연스러운 인 이다. 그러나 궁극적으로 다자원조 정책을 이끌어갈 원칙을 설정하는 작업이 긴요하다.

한국의 개반원조의 진과 효과성을 확보하기 위해서 이러한 원칙의 설정과 더불어 이러한 원칙을 실질적 으로 구현하기 위한 명백한 전략지침을 만드는 것이 필요하다. 뉴질랜드의 「Multilateral Engagement
Strategy(MFS)」와 같은 것을 예의 하나로 들 수 있다. 이러한 전반적인 전략지침 내에서 개별적인 다자가구 에서의 전략시침이 작성되어야 한다. 스위스의 경이는 전략적이고 외교정책적인 측면, 결과, 특정 지표에 기 초한 효율성의 입증을 기준으로 하여 다자원조 기구들 을 세 등급으로 분류하여 가장 높은 등급의 다자원조 기구의 경우, 기구에 특별한 전략 페이퍼(institutionspecific strategy paper)를 작성하여 치밀하게 대응하 고 있다 ${ }^{25}$.

\section{2. 다자원조의 양적 확대와 질적 제고}

총 원조액의 증가와 더불어 다자원조의 액수를 늘여아 한다. 2006년도 한국의 ODA 총액은 4억 5,500만 달 러이고 이 중에서 다자원조의 총액은 7,900만 달러였 다. 우러와 경제규모가 비슷한 네덜란드 및 스페인과 의 비교가 그 뙬요성을 뚜렷하게 보여준다. 네덜란드 의 경우는 총 54 억 5,200 만 달러 중 11 억 6,900 만 달 러를 다자원조에 할애했고, 스페 인은 총 38 억 1,400 만 달너를 ODA로 투입한 가운데 이중에서 17 억 2,200만 딜러를 다자원조로 제공했다.

원조 총액의 증가와 더불어 다자원조를 증가시킬 경 욱, 국제금융기구가 아닌 비금응기구에 대한 시원을 비율을 높여야 한다. 비금응기구에 내한 지원을 증가 시키되 조긴이 수빈되지 않은 자반적 출연금을 늘려야 한다. 특히 국제게발 다자기구의 상징이라고 할 수 있 는 UNDP와 같은 국제기구의 핵심기금에 대한 지원을 내폭적으로 늘려야 한다. 이러한 핵신기여금의 제공을 
통해 다자기구의 원조의 전락적인 방향을 걸정하는 공 여국 자문위원회라든가 다른 실무토론모임(w orking forum)에 참여할 수 있다.

국제적으로 조긴부 자발적 출연금 (earmarked voluntary contributions)의 제공이 증가하고 있는 가 운데 이에 대해 한국이 어떠한 입장을 취하여야 할 것 인가의 문제가 있다. 중장기적으로는 비금융기구의 자 반적 출연금 중 여러 해에 걸쳐 연례적으루 제공하는 핵심기여금(multi-annual oore contributions)의 제 공을 원칙으로 하여야 하며, 조건비 자발적 출연금의 제공을 예외적인 것으로 하여야 한다.

그러나 단기적으로 다자기구와의 협력을 통해 자체의 원조역량이 강화될 때까지 조건부 다자원조의 중요성 을 간과하여서도 안 된다고 본다. 이렇게 득정 국가별 혹은 트정 주제별 조건부 출연금을 제공할 할 경우에 있어서도, 다른 공여국들과의 효과적인 조정 (coordination)이 가능하도록하여야 할 것이다.

\section{3. 평가기준에 의한 제한된 대상의 선정과 집중적 지원}

\section{가. 제한된 대상의 선정과 집중적 지원}

다자원즈의 대상을 제한하여 집중하여야 한다. 즉 다 수의 다자기구에 골고루 침여하지 않고 소수의 다자기 구에 집중하여야 하머, 다수의 분야가 아닌 제한적인 분야에서 실질적인 기여를 하여야 한다. 장기적으로 적은 수의 다자기구에 지원을 집중하여 이러한 다자기
구에 서 상대적으로 지원규모가 큰 국가가 될 경우, 이 러한 다자기구의 정책방향을 규정짓는 데 있어서 뿐만 아니라 개도국과 대화를 하고 다자기구의 전 시구적인 규범과 기준의 설정에 강력한 빌언권을 가질 수 있게 된다.

뉴질랜드의 경우, 2007 년도 10 월 현재 33 개 다사기구 와 헙럭하고 있는데, 그 중에서 21개 기구에 연례적 핵 심기금(annual core fund)을 제공하고 있다. 33 개 기 구 중에서 높은 순위의 파트너로 간주되는 10 기의 기 구의 할동에 집중하여 감시를 하고 책임성을 확보하고 자 한다. 또한 이 중에서도 세계은행(IBRD), 유엔개발 계획(UNDP), 그리고 아시아개빌은행(ADB)을 다자원 조의 3대 파트너로 하고 있으며, 여러 분야 중에서 특 히 극단적인 번iㅣㄴㅇㅢ 제거, 인도주의적 대응을 지원하 녀, 인권을 보호하고 촉진하는 것에 중접을 두고 있다.

소수의 제한된 대상에 집중하기 위해서는 선별 및 지 원의 지속여부를 판단하기 위한 기준을 필요로 한다. 주요 공여국들은 시속적이고 포괄적인 평가기준을 통 해 다자기구에 대한 원조제공을 체계적으로 평가해 오 고 있다. 이와 관련하여 보편적으로 중시되는 기준을 살펴보면 다음과 같다.

\section{나. 평가의 기준}

1) 유관성(relevance)

우선 유관성이 다른 기준에 앞서 가장 중요한 기준이 되어야 한다. 이는 다자원조의 대상이 얼마나 한국이 
추구하는 가치, 정책, 전락적인 목표와 유관한가를 펑 가하는 기준이다, 구체적으로 한국정부가 추구하고자 하는 정책목표와한국정비-가 우선시하고자 하는 것을 잘 반영할 수 있는 소수의 다자기구와 소수의 제한적 인 분야에서 신진적인 기여를 하여 야 힌다.

\section{2) 효과성(effectiveness)}

다자기구의 효과성(effectiveness)이 또 다른 기준이 되어야 한다. 이는 구체적으로 양자원조를 비롯한 다 른 기금 제공통로와 비교하여 다사기구 자체가 설정한 목표에 얼나나 효과적으로 기여하는가를 의비한다. 즉 다자원조와 양자원조의 비교우위는 무잇인가, 어떤 종 류의 원조가 다자적으로 가장 잘 관리될 수 있고 어떤 중류의 원조가 양자적으로 좀 더 잘 관리될 수 있는가 에 대한 연구 역시 필요하다 ${ }^{26)}$.

다자기구의 효과성에 대한 평가를 할 때 자체의 평가 뿐 아니라 다른 공여국 혹은 연구소가 다자기구에 대 한 모니터링을 통해 만든 평가도 중요한 기준이 되어 야 한다. 또한 여러 공여국에 의한 다자평가체제에의 적극적인 침여도 긴요하다.

이를 위해 구체적으로 다사기구의 효과성을 평가하기 위한 한구 자체의 펑가체제를 구축하여야 한다. 이러
한 예로서 영국정부가 시행하고 있는 「다자효과성틀 (Multilateral Effectiveness Framework: MEFF)」 을 들 수 있는데, 이는 「결과에 기초한 관리(ResultsBased Management)」접근법을 사용하여 영국징부 가 지원하고 있는 다자기구의 효과성을 평가하는 강 력한 기제이다. 영국정부는 이러한 평가결과를 다자 기구에 대한 전략에 반영하고, 나아가 이에 기초하여 재정지원에 관한 의사결정을 한다. 이러한 개별적인 평가체제에 디하여, 「다자기구성과평 가네트워크 (Multilateral organizations Performance Assessment Netw ork: MOPAN) 와 같은 다국적인 평가체제에 찬여하는 것이 필요하다미.

\section{3) 전략적 영향력(strategic influence)}

이는 구체적으로 다자기구와의 내화와 다자기구의 집 행부(governing body)에서의 활동을 통해 다자기구의 의사결정, 운용횔동, 그리고 자원의 분배에 전략적인 영향을 행사하는 것을 의미한다. 이러한 전략적인 영향 력의 행사가 가능한가가 시원 대상의 선별과 이더한 대 상에 대한 지속적인 지원 여부의 기준이 되어야 한다.

다자기구를 통해 원조를 제공하는 경우, 양자원조와는 달리 영향력의 손실이 운뎌된다. 따나서 이더한 다사 기구의 정책걸정과 결정의 집행에 있어서 합러적인 영

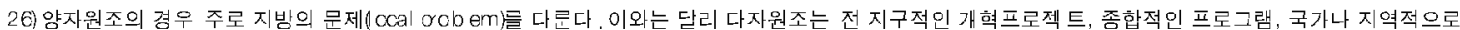
줌요한 프로젝드에 유용하다. 구체적으로 대규모의 난민을 지원히는 것과 같은 긴급구호 프로젝드, 도고나 철도의 건설과 같은 대규모의 개발 프로젝드, 환경과 빈근 그리고 여성개발 $\overline{5}$ 범지구적 과제 $(G$ oba lssue) 해결에 유옹히다. 국제기구는 정치적민 정남성을 보유히고 전문성과 재정적민 소건의 면에 서 명백한 비교우위를 가지고 있는 분이와 기능에 집즘하여이 한다.

27) MOPAN은 세계은햄 (BRD)과 같은 국제금융기 구와 유엔개발계 획(NNDP)과 같은 국제기구의 두삼원조 점잭을 평가하고 원조규모를 조정하는 경제협력 기구/개발원조위 원회(OECDICAC)의 국가 간 주요한 비공식 현의기구로 서 염국, 프랑스, 네덜란드. 스웨덴, 카나다, 스위스, 핀란드, 노르웨이, 덴마크, 오 스트리아 등 선진 10개 공여국으로 구성되어 있다. 2007년 12월 영국 런던에서 개최된 MOPAN 운영위원회 기 한국에기 옵서버 지격을 부여히기로 했으 며, 이로써 다자원조 기구의 시업 효과성, 시업녈 예산배분의 적정성, 다자기구 운영의 분아녈 - 지 역녈 균형성 듬에 대한 검토와 분석을 통하여 원조사업 수행평가 늠력을 제고할 수 있기 되었다 
향력을 가지기 위한 전락적인 도구를 갖추어야 한다. 덴마크의 경우도 적은 수의 국제기구에 집중하여 선별 된 국제기구에서 정책형성에 좀 더 많은 영향을 미치 기 위하여 많은 노력을 강조하고 있달․ 한국정부의 정책적인 우순순위와의 관계 속에서 다자기구에시의 영향력을 극대화하기 위한 도구를 생각해보면 다음과 같다.

첫째, 이러한 도구의 하나로서 한국이 원즈를 제공하 고 있는 다자기구의 고위직책에 자국의 전문가를 두도 록 하는 것이 필요하다. 스위스의 경우, 다사기구들을 세 등급으로 분류하여 가장 높은 등급의 기구의 경우 이 기구의 잡행기관(governing body)에서 자국을 대 표할 수 있도록 노력한닫‥ 그 밖의 다자원조 기구에 서도 발언권을 확보하기 위한 자국인 진출에 많은 노 럭을 경주하고 있다. 다자원조기구에 자국인 직원을 둔다는 것은 빌언권을 가지지 위한 측면과 감독을 한 다는 의미뿐만 아니라 능력 있는 인적자원을 가용하게 한다는 의미가 있다.

둘째, 영국의 예에서 볼 수 있는 것처럼 다자원조 기구 와의 관계 속에서 정책의 우선순위를 구체화하는 $\ulcorner$ 기 구전락 페이피(institutional strategy paper: ISP)」와 같은 것을 작성한다. 이를 통해 다사원조 기구와의 협 럭 속에서 한국이 추구하는 정책목표를 달성하기 위해 이떻게 기여할 것인가를 밝힘으로씨 영향력을 행사할 수 있다.

셋째, 다자기구와 골격협정 등을 체걸한다. 이러한 에 로서 2006년 4윌에 한국정부와 유엔 개발계획(UNDP) 이 체결한「Partnership Framework Agreement,를 들 수 있다. 이 협정은 한국 정부가 아시아와 아프리카 지역의 최빈국에게 1,000 만 달러 지원을 약정하면시 체결한 것으로서, 한국정부와UNDP가 서로의 개발목 적, 정책, 이선순위 분야에 익숙하도록 하는 것으로서 이를 통해 헙러관계를 강화는 것을 목적으로 한다. 이 역시 영향력으로 전이될 수 있다.

넷째, 핲서 언급한 다자기구의 효과성을 평가하기 위 한 개별적인 체제의 구축과 다국적인 펑가체제에의 찬 여 역시 해당 다자기구에서의 영향력 행사에 중요한 역할을 수행한다. 이와 더불어 견해를 같이 하는 국가 들과의 연합(alliance)의 구촉 역시 필요하다.

\section{4) 파트너십(partnership)}

파트너십이라는 기준은 푸체적으로 다자기구가 개도 국 및 다른 국제기구와 갖는 파트너십을 의미한다. 위 에서 언급한 기준들과 비교하여 그 중요도가 상대적으 로 떨어지기는 하나. 다자기구가 문제해결을 위해 다 른 게발원조의 주체와 맺고 있는 유대가 점차적으로 증요해시고 있어 이더한 요인데 대한 평가 역시 중요 하다고 본다.

\section{4. 관련 부서간의 조정}

28) M nstry of Foreign Affa's of Denma'k, Denmark's Mutilatera Deve opmer. Coopeation Towards 2015 (Mrist'y of Foregr Affairs: Coperhager. Alugus 2008). p. 5. 29) SECO, Sw zer and'sMut ateral Development Cooperat on Stragy: An SDC-SECO Guide ne (SECO: Berne, 2005 ) p.12. 
다자원조를 다루는 국내조직의 문제에 관심을 두어야 한다. 다자주의에 있어서 통일된 행동을 취하기 위해 서 관련 부서간의 좀 더 나은 조정이 특히 필요하다. 한국의 경우, 외교통상부가 유엔체제(UN System)에 의 기여금(contribution) 제공에 책임을 지고 있는 반 면, 기획재정부가 세계은행 $(\mathrm{BRD})$ 이나 아시아개발은 행(ADB)과 같은 국제금융기구(IFIs)에의 출연금에 책 입을 지고 있으면서 이들 간에 협럭이 제대로 이루어 지고 있지 않다는 비판이 많다.

덴마크의 경우에서 보듯이 외교부가 총체적인 정책과 전략의 개발에 짐중하는 가운테, 유엔 내표부와 워싱 턴의 대사관이 틈징 국제기구에 제공되는 다자원조에 일차적인 책임을 지는 분권화된 체제를 고려해봄 직하 다. 이러한 분권화가 특정 국제기구와의 지속적인 대 화의 질과 호과성을 강화할 수 있기 때문이다.

\section{5. 기타}

다사원조를 촉진하기 위한 근본적인 방편의 하나로서 국민을 설득할 전략을 가지고 있어야 한다. 다자원조 를 제대로 하기 위해서는 개발관련 국제기구에 대한 심층적인 연구가 필요하며, 동시에 이러한 국제기구로 의 한국인 진출이 활발하게 전개되어야 한다. 유럽연 합이 공동으로 개발원조 사업을 활발하게 전개하고 있 는 것과 관련하여 한국, 중국, 인본이 비록 작은 규모 로 출발한다고 해도 공동으로 기발원조 사업을 시작하 는 이니셔티브를 쥐는 갓도 필요하다고 생각된다.

\section{VII. 결론}

이제끼지 다자원조에 관한 기본적인 논의와 더불어 다 사원조의 중요성을 살퍼보았고, 이더한 눈의를 기초로 하여 한구ㅈㅓㅓㅇ부가 취하여야 할 다자원조의 정책방항을 모색해 보았다. 이러한 논의는 산빌적이고 부분적이기 는 하나, 한국정부도 정책 방향의 일부로서 언급하고 있는 부분이기도 하다. 그러나 문제는 이러한 것들이 당위적인 것에 머물고 있다는 전이다. 이는 확고한 원 조철학의 결여에 기인하는 것으로서 한국이 왜 다자주 의에 적극적으로 침여하여야 하는가에 대한 강한 인식 의 전환과 더불어 행동이 수반되어야 함을 보어준다.

러기(John Ruggie)는 다자주의(multilateralism)를 「3 개 이상의 국가들이 보편화된 행위원칙 (generalized principles of onduct)에 따라 정책을 조정해 나가는 방식스로 정의하고 있다. 여기서 보편화된 행위원칙 이란 득정 국가의 득정 이이과 득정 상황에 따른 읹기 응변적인 대응이 배제된 행위원칙으로서 불편부당성 (impartiality), 일관성(consistency), 국제법에 대한 존 중(respect for international law)이라는 요소들을 내 포한다.

러기는 이러한 일반화된 행위원칙에 더하여, 다자간 협력체제 내의 일국에 대한 외부 행위자의 공격을 참 여국 모두에 대한 공격으로 간주하는 것과 같은 불가 분성(indivisibility)과 관련 국가들이 항상 그리고 모든 이슈에 있어 단기적이고 개번적인 이득을 기대하기 보 다는 장기적이고 공동의 이득을 추 구한다는 확산된 상 호성(diffuse reciprocity)을 다자주의의 또 다른 특징 
으로 간주하고 있다 ${ }^{30}$.

이더한 러기의 정의에 따르면, 다자주의는 외교에 있 어서 자신의 이익뿐 아니라 타국의 이읙도 최대한 고 려하는 공동체 의식을 중요한 밑바탕으로 하여 국가이 익과 국제사회 전체의 이익 사이의 균형을 추구하는 것을 전제로 하고 있다. 이러한 다자주의 속에서 어떠 한 국가든 자의적으로 행동을 할 수 있는 여지가 적어 지며, 국제관계의 결과가 쌍무적 관계에시와 같이 적 니라한 협상력(naked bargaining power)에 의거하지 않고 합의된 원칙에 의해 결정될 수 있는 가능성이 높 아진다.

군사력이나 경제력을 통해 국제사회를 좌지우지할 능 력을 보유하지 않은 한국과 같은 국가는 국제적으로 합의된 법, 기준, 규번에 기조한 국제질서의 수혜자가 된다. 이 때문에 이러한 국제질서의 수립에 직극직으 로 참여하여야 하며, 이러한 국제질서의 수립에 소요 되는 비용-의 일정한 몫을 부담하여야한다.

덴마크를 위시한 부ㅇㅠㅠ립 국가들은 개방된 경제를 가지 고 있는 소국(small states)으루서 미래의 도전에 대응 할 수 있는 효과적인 다자체제에 국가이익의 걸려있다 고 판단하고 다사주의에 중요성을 다고 있다. 이 때문 에 이들 국가들은 실질적인 개발원조를 국제기구를 동 해 제공하는 데 대체적으로 인색하지 않다. 이러한 다 자원조는 이들에게 소국으로서 기대할 수 있는 것을 넘어선 영향력을 가질 수 있는 기회를 제공하기 때문
이다. 다자원조를 통해 보다 넓은 지역에 대한 복지와 구제활동을 지원함으로써 영향력을 전 지구적으로 확 대하고 국제개발, 인권, 인도적 지원 등에 있어서 발언 권을 가질 수 있기 때문이다.

한국 역시 국제가구를 퉁한 다자원조에 적극적으로 나 설 때 국제개발 이슈의 논의에 있어서 발언권을 행사 할 수 있다. 즉 다자원조에 기여를 함으로써 국제사회 의 개반을 위한 목표와 전략의 형성에 침여하게 되고, 이를 통해 전 지구적인 기발노력의 방향을 모색하는 것을 도울 수 있다. 개발을 위한 목표와 전략의 설계가 주요 공여국에게만 전부 남겨질 경우, 한국과 같은 국 가의 이해관계는 무시될 수 있는 것이다.

양자원조와 다자원조를 이익(interests)의 문제와 가치 (values)의 문제로 이분법적으로 생각하는 경우도 있 으나, 이는 가치를 통해 이익을 추구한다는 장기직이 고 기시적인 면을 제대로 고려하지 않은 소치이다. 스 위스의 경우, 다자원조와 관련하여 자국의 역할을 이 해당사사(stakeholder)로서의 역할과 동시에 분담사 (shareholder)로서의 역할로 보는데, 이러한 역할 인식 이 필요하다.

앞서 살퍼보았듯이 한국의 다사원조의 현실과 방향 은 단기적인 국가이익의 추구에 많이 내몰되어 있다. 다자원조에 적극적 으루 참여하는 것은 국익추구의 요소와 더불어 책임적인 요소가 동반된다는 인식이 필요하다. 좀 더 거시적이고 장기적인 관젇에서의 국

30) John Gerard Rugg e. "Mu tilaera ism: The Ana:cmy of an Inst ution," Intenat ona O'garizat on, vo, 46, no, 3 (1992). 
가이익을 의미하는 「계몽된 이익(enlightened selfinterest),이라는 것을 중요시 하여야 할 필요가 있다.

이러한 인식의 전환과 더불어 다자원조와 관련하여 가 강 중요한 것은 이떠한 기준으로 국제기구를 통한 다 자원조에 관여할 것인가의 문제이다. 이와 관련하여
어떤 국제기구가 전 지구적 수준과 국가수준에서 확실 하게 바람직한 결과를 가저올 수 있는가, 어떻 게 가장 큰 효율성에 도달할 수 있을까. 국제기구에서 어떻게 한국의 개발징책 목표를 달성할 수 있을까를 묻는 것 이 필요하다. 


\section{[ 참고 문헌 ]}

\section{1. 국내문헌}

대한상공회의소, 경제정책정보.

(http://www.korcham.net/EconNews/Econlnf o/CRE0 4102R.asp?m_DatalD=31131)

외교통상부 인도지원과, $\mathrm{ODA}$ 국의 제공 자료.

한국수출입은행, 원조용어집. (http://www.koreaexim.go. kr)

\section{2. 외국문헌}

Department of Public Information of the United Nations (12/November/2007), Member States Pledge Approximately $\$ 80$ Million in Support of United Nations development Activities for 2008, General Asse mbly DEV/2646.

John Gerard Ruggie (1992), "Multilateralism: The Anatomy of an Institution," , vol. 46, no. 3, International Organization.

Ministry of Foreign Affairs of Denmark (August 2008), Denmark's Multilateral Development Cooperation Towards 2015: p. 5, Copenhagen.

South Center (1996), For a Strong and Democratic United Nations: A South Perspective on UN Reform, pp. 87-88, Geneva.

OECD, DAC Statistical Reporting Directives. (h ttp://www. oecd.or g/dataoecd/36/32/31723929.h tm\#8,9,10)

OECD, Stat Extracts.http://stats. oecdorg/wbos/lndex aspx?DatasetCode=ODA_DON OR) SECO (2005), Switzerland's Multilateral Development Cooperation Strategy: An SDCSECO, p.12 Guideline, Berne.

UNDP, Annual Report 2008. (h ttp://www. undp.org/publications/annualreport2008/resources.shtml)

United Nations Office on Drugs and Crime, Fundings and Partnerships. (http://www. unodc.org/uno dc/en/donors/in dex.html) 